\author{
Sustinere \\ Journal of Environment and Sustainability \\ Volume 3 Issue 3 (2019) 127-143 \\ Print ISSN: 2549-1245 Online ISSN: 2549-1253 \\ Website: https://sustinerejes.com E-mail: sustinere.jes@iain-surakarta.ac.id
}

\title{
RESEARCH PAPER \\ Web-GIS mapping for watershed and land cover area in Bengkulu
}

\author{
Ernawati Ernawati ${ }^{1}$, Arie Vatresia ${ }^{1}{ }^{*}$, Breygas Andara $^{1}$, Rendra Regen ${ }^{2}$ \\ 1. Dept. of Informatics, Faculty of Engineering, Universitas Bengkulu, Indonesia \\ 2. Ministry of Enviroment and Forestry, Natural Resources Conservation Agency of Bengkulu, Indonesia
}

Article history:

Received 22 August 2019 | Accepted 3 November 2019 | Available online 1 December 2019

\begin{abstract}
Naturally, watershed has a function to accomodate and store water from rainfall to the lake or to the sea. It is affected by land activities and shaped as a boundary of topographic land and as a separator from the sea. Managing the area is one of essential steps for further environment assessement, i.e. decreasing water quality and vulnerability to landslides or floods. However, the ability of web-GIS technology to help the management of watershed area in Bengkulu is still unknown. Here, we showed how the process of Web GIS development for managing the watershade in Bengkulu could be achived. This study mapped the 2018 land cover area of Rindu Hati Sub-watershed by utilizing Landsat 8 satellite images using the Maximum Likelihood method. The land cover map was then processed and displayed using webGIS media. The results showed that the system accuracy for ground truth land use model result was $77.4 \%$ which could be accepted as a good result. Further assessment of pixel validation could be one of the future research. We anticipated that the results could be a starting point for more sophisticated area cover of Sumatra and Indonesia. Furthermore, this could be a major development on knowledge discovery in environment and ecology.
\end{abstract}

Keywords: WebGIS; DFD; land cover; watershed; Bengkulu

\section{Introduction}

Watershed (DAS) is a land area which is a unit with the river and its tributaries, which functions to accommodate, store and drain water from natural rainfall to lakes or sea. Watershed's boundary on land is a topographic separator and boundaries in the sea to the waters which are still affected by land activities (Departemen Kehutanan Republik Indonesia, 2009; Presiden Republik Indonesia, 2012). This means that the watershed consists of system components that affects to each other, or it can also be explained that changes in a part of the system influences the other system even though the space is quite far apart. In another term, watershed management is defined as human efforts in regulating the reciprocal relationship between natural resources with humans in the watershed and all its activities in order to realize

${ }^{*}$ Corresponding author. E-mail: arie.vatresia@unib.ac.id

DOI 10.22515/sustinere.jes.v3i3.85 
the sustainability and harmony of ecosystems and to increase the sustainable use of natural resources for humans (BPS, 2017). However, The Ministry of Environment and Forestry states that, in principle, watershed management is a land use arrangement or optimization for various rational interests as well as other practices that are environmentally friendly, so that it can be assessed with ultimate indicators quantity, quality and continuity of river flow at watershed outlets (Departemen Kehutanan Republik Indonesia, 2009). Based on this definition, land use factors play an important role in watershed management.

Rindu Hati Watershed covers an area of 51,500 ha and is located in two region in Bengkulu: Middle Region of Bengkulu and The City of Bengkulu. The main river in this watershed is the Air Bengkulu River. The watershed is divided into three sub-watersheds (Andriansyah \& Mustikasari, 2011; BPDAS Ketahun, 2006), namely the Rindu Hati, Susup and Bengkulu Hilir sub-watersheds. So far, there is no special map that describes land cover in the DAS Air Bengkulu area, specifically the Rindu Hati sub-watershed area. The land cover map in the watershed area is important to understand the problems that occur in

Bengkulu waters such as decreasing the quality of clean water or vulnerability to landslides and floods. According to Waluyaningsih (2008), changes in land use and watershed management practices affect erosion, sedimentation and water quality.

Modeling land cover areas can be done by utilizing remote sensing and geographic information systems, namely the utilization of satellite images in this study in the form of Landsat 8. The results of this study can be taken into consideration in determining local government policy in making regional regulations on land cover in the watershed area. As the development of Information Technology (IT) framework proposed by (Vatresia et al., 2017), embedded technology is important to improve the performance of monitoring and conservation activity in Indonesia. Since the Web-GIS was also proposed as one of the lattest solution to develop the embedded technology (Vatresia et al., 2017) this study would try to develop web GIS for mapping watershed and land cover model in Bengkulu, which was not integrated with this technology (Muhsoni, 2009; Wahyuni, 2015). Furthermore, this study would also produce information about the land use change in Rindu Hati River that would be helpful for data integration accross Indonesia.

\section{Literature review}

\subsection{Bengkulu watershed}

Watershed is a land area which is an integral part of the river and its tributaries, which functions to collect, store and flow rainwater to lakes or to the sea, and a land boundary of topographic separators and boundaries in the sea to water areas that are still affected by land activities (Departemen Kehutanan Republik Indonesia, 2009). Watershed is generally defined as an expanse of area/area which is limited by topographic boundaries (ridges) that receive, collect rainwater, sediment and nutrients and drain it through tributaries and dispose it to the main river to the sea or lakes (BPDAS Ketahun, 2006).

Air Bengkulu watershed covers an area of 51,500 ha and is located in two regions in Bengkulu; the Central Region of Bengkulu and the City of Bengkulu (Kodontie \& Syarif, 2010). The main river in the watershed is Air Bengkulu. The watershed is divided into 3 subwatersheds, namely Rindu Hati, suspended sub-watershed, and sub-watershed of Bengkulu Hilir 
(Andriansyah \& Mustikasari, 2011). The six tributaries that flow to the Air Bengkulu River are Sus Sus, Rindu Hati River, Kemumu River, Pasemah River, Sialang River and Muara Kurung River. The suspended river is part of the suspended sub-dab. Rindu Hati and Kemumu Rivers that form Rindu Hati Sub-watershed. The Pasemah River, Sialang, and Muara Kurung formed the Lower Bengkulu Sub-watershed.

\subsection{Mapping model}

According to Gunawan (2014), the model is a representation of an object or idea in a simplified form of conditions or natural phenomena. The model contains information about a phenomenon made with the aim of studying the actual system phenomena. The model can be an imitation of an object, system or event that is actually only contains information that is considered important for review. Mapping is the study of the appearance of the earth that uses a tool and produces accurate information. In other words, mapping and geography are the same because they both discuss something under and above the earth, as long as affect the surface of the earth (Ambarwati \& Johan, 2016).

From the model definition and mapping above, it can be concluded that the mapping model is a simplified representation of the appearance of the earth to display information on the surface of the earth important to study, as in this study, the information is in the form of land cover information (Susilo, 2011).

\subsection{Web-based Geographic Information System (Web-GIS)}

Geographic Information System (GIS) is a system designed to capture, store, manipulate, analyze, organize and display all types of geographical data. GIS is inseparable from spatial data, which is a data that refers to position, object and relationship between them in the space of the earth. Spatial data is one item of information about the earth including information about the surface of the earth, under the surface of the earth, waters, marine and under the atmosphere (Irwansyah, 2013).

GIS consists of two types of data, namely spatial and attribute data. Spatial data are the data that refer geographically to representations of objects on earth. Spatial data are generally based on maps that contain interpretations and projections of all phenomena that are on earth while attribute data are the data that present the aspects of description/explanation of a phenomenon on the surface of the earth in the form of words, numbers, or tables.

WebGIS is a GIS application that can be accessed online via the internet/web. In the WebGIS configuration there is a server that functions as a MapServer which is in charge of processing the map request from the client and then sending it back to the client. In this case the user/client does not need to have GIS software, only uses internet browsers such as Internet Explorer, Mozilla Fire Fox, or Google Chrome to access GIS information on the server (Purwanto, 2014). 


\section{Research method}

Since the problem of watershed and monitoring process was well understood by the Ministry of Environment and Forestry, the waterfall methodology would be suitable to address this problem (see Figure 1). This methodology would also be beneficial for the developer, since the changes over the design and analysis would be very limited (Sommerville, 2010).

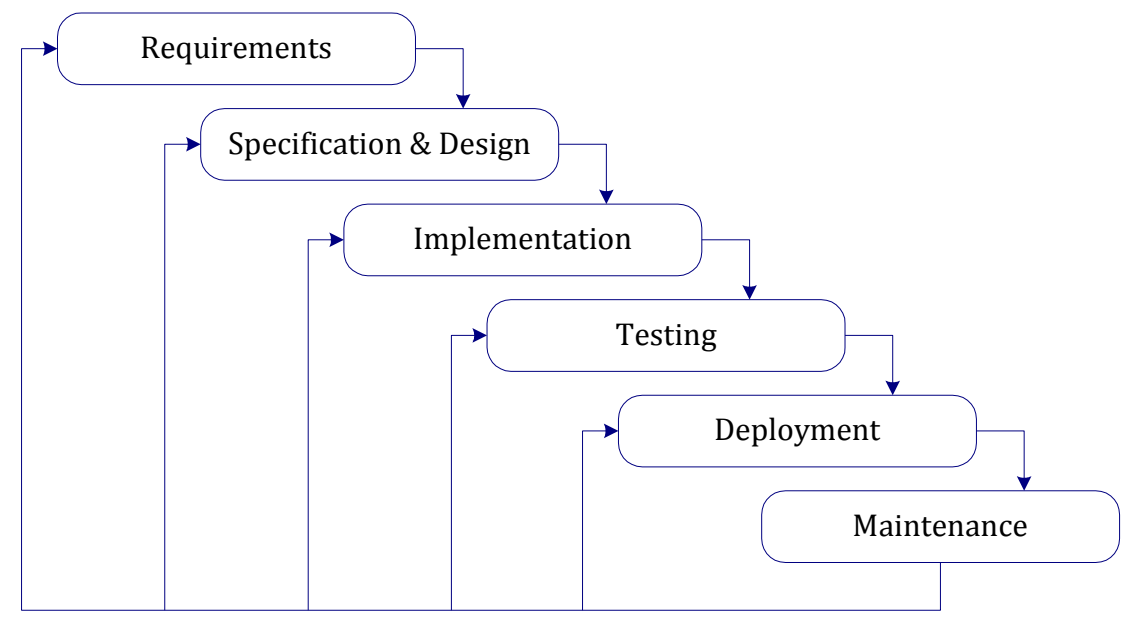

Figure 1. Waterfall methodology (Sommerville, 2010)

The stages of waterfall methodology would be defined as follows. First of all, the investigation phase is carried out to determine whether a problem has occurred or not and whether there an opportunity for an information system to be developed. At this stage, a feasibility study needs to be conducted to determine whether the information system to be developed is a feasible solution. Second, the analysis stage aims to find the needs of users and organizations and analyze existing conditions before the new information system is implemented. Third, the design stage aims to determine the detailed specifications of the information system components: human, hardware, software, network and data, and information products that are in accordance with the results of the analysis phase. Fourth, the implementation stage is to obtain or develop hardware and software (program coding), conduct testing and training, and transfer to a new system. Finally, the maintenance stage is carried out when the information system has been operated. At this stage, there are monitoring, evaluation and change (improvement) carried out if necessary.

Data flow diagrams (DFD) are graphical representations of a system. DFD describes the components of a system, data streams between these components. The approach and representation of DFD is a structure analysis approach. This approach tries to see the system first in outline (called as top level) and then breaks it down into more detailed parts (called as low level) (Budiani, 2010). DFD is drawn starting from the top level and to the following level. The guidelines in drawing DFD, according to Budiani (2010), are as follows:

1. Identifying all external entities involved in the system in advance. This external unity is the source of data flow to the system and the recipient's destination data flow resulting from the system.

2. Identifying all inputs and outputs involved with external entities recorded in a matrix. 
3. Drawing a context diagram based on external unity and input-output that has been identified. One context diagram contains one drawing and one process and is usually given a process number of 0 , as this process represents the process of the entire system.

This study was conducted in Rindu Hati Sub-watershed area. This area is located in Central Bengkulu District, precisely in Taba Penanjung Sub-district, which includes several villages, namely Karang Tengah, Kota Niur, Rindu Hati, Taba Penanjung, Taba Teret, Tanjung Heran and Tanjung Raman villages. In this study, land cover mapping used was the 2018 Landsat 8 satellite image data (Path 125 Row 63) which was obtained from the website of USGS Earth Explorer https://earthexplorer.usgs.gov/.

The land cover classification method used in this study was the Maximum Likelihood classification method. This method considers the average value and diversity of anthrax and channel (covariance). The stage of land cover classification process included the process of calculating the OIF and creating training areas to be used in classifying the land cover class. These stages were conducted by using the ENVI 5.3 application. After obtaining a land cover map, the map was converted into a JSON file, so that it could be processed into a web-based land cover map. The research flow chart can be seen in Figure 2 .

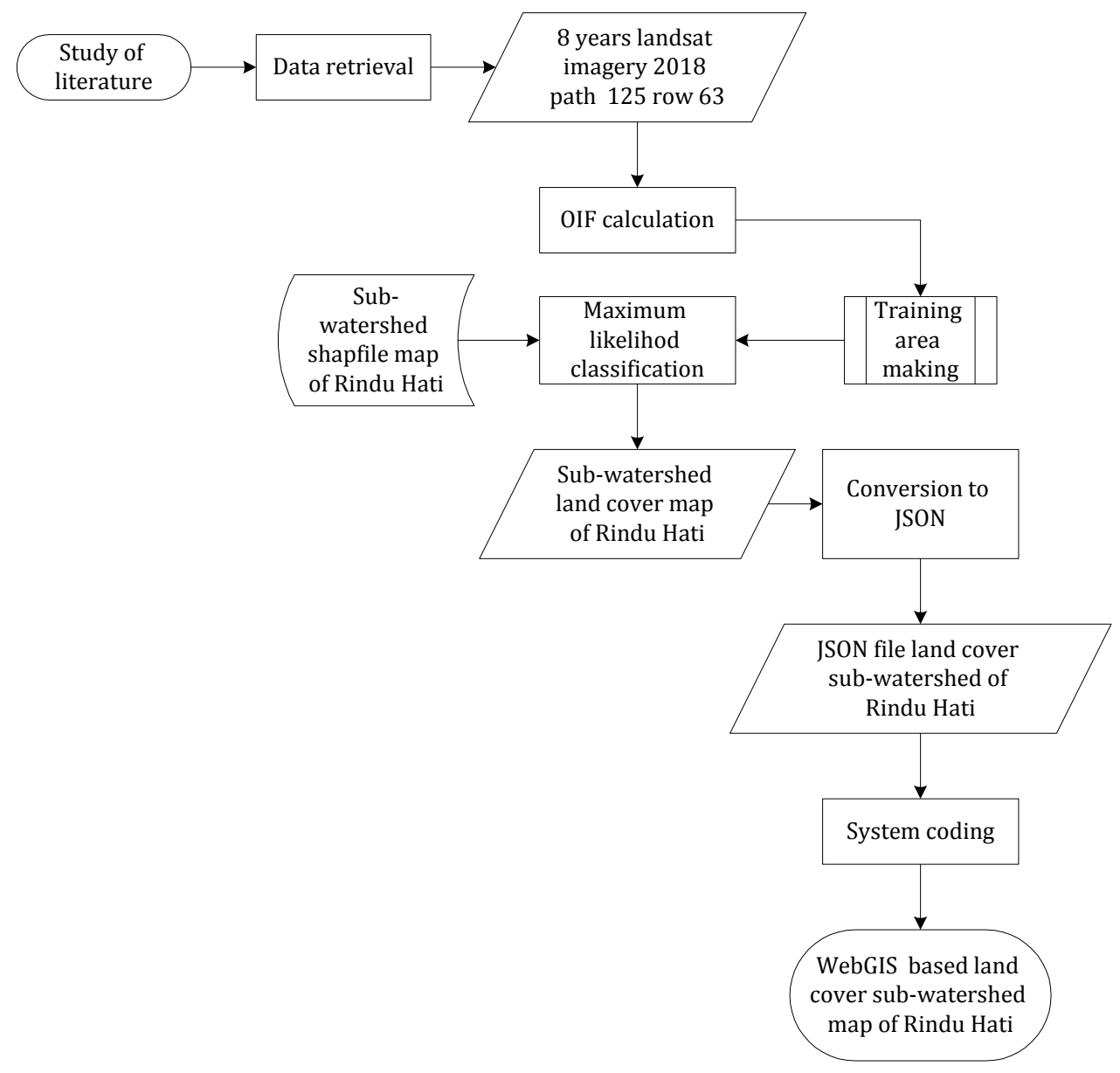

Figure 2. Research flow chart 


\section{Result}

In this study, there were two main steps conducted, namely image processing and system development. This section discusses those two steps in more details.

\subsection{Image processing}

The first step in image processing was determining the best band combination using the Optimum Index Factor (OIF) method (Arhatin, 2007). This OIF calculation aimed to choose the best band combination to find out the initial picture in identifying the pattern of distribution of land cover. In this study, the best band combination was a combination between band 7, band 5 and band 2 as can be seen in table Table 1 .

Then, after determining the best band combination, the next step was making training area for each land cover class, as in this study, there were 9 classes, which are built areas, open areas, rice fields, empty rice fields, forests, plantations, water bodies, clouds and cloud shadows. Once the training area was created, the land cover classification was then processed using the maximum likelihood method.

Table 1. The results of OIF calculation

\begin{tabular}{ccccc}
\hline No & \multicolumn{3}{c}{ Band combination } & OIF \\
\hline 1 & b7 & b5 & b4 & 5825.46 \\
2 & b5 & b4 & b1 & 5478.32 \\
3 & b5 & b4 & b2 & 5363.58 \\
4 & b7 & b5 & b2 & 5323.77 \\
5 & b6 & b5 & b4 & 5226.97 \\
\hline
\end{tabular}

The last process in the image processing step was converting the land cover map into a JSON file. This process was conducted using an online converter provided by IGISMAP (https://map.igismap.com/con-verter).

\subsection{System development}

\subsubsection{Analysis}

Functional analysis means analyzing functions on system to be built (Guritno \& Rahardja, 2011). Functions in the system above are the features available in the system. The followings are the processes done by the system.

a. The system projected a map of regional land cover the Rindu Hati sub-watershed.

b. The system displayed extensive information per land cover.

c. The system displayed land cover data on a chart or graph.

Non-functional analysis is an explanation of the needs of software and hardware in making a system. The software requirements (Pratama, 2015, 2017) for making this application were Windows 10 Pro Operating System as the operating system in this study, and Exelis Envi 5.3. to process Landsat 8 image data in making training areas, cutting images, and classifying land covers. In addition, there were also ArcGis 10.4. was used to convert the classification of 
processed data with .dat extension to .shp, so that it could be processed into JSON data, VScode 1.30.1 as a text editor in WebGIS coding, XAMPP v3.2.2 as a local server in WebGIS development, Wireframe Pro to make the WebGIS system display designs, Google Chrome 71.0 to access WebGIS, and Google Earth Pro 7.3.2 to carry out the visual image interpretation. Meanwhile, the hardware used for making this application were Thinkpad x230 laptop, Intel Core i5 processor, and 4 GB sized RAM.

\subsubsection{Design}

The system design stage was done after completing the system analysis stage. The designs made in this system were the design of Data Flow Diagram (DFD) and interface design (Mulyanto, 2008).

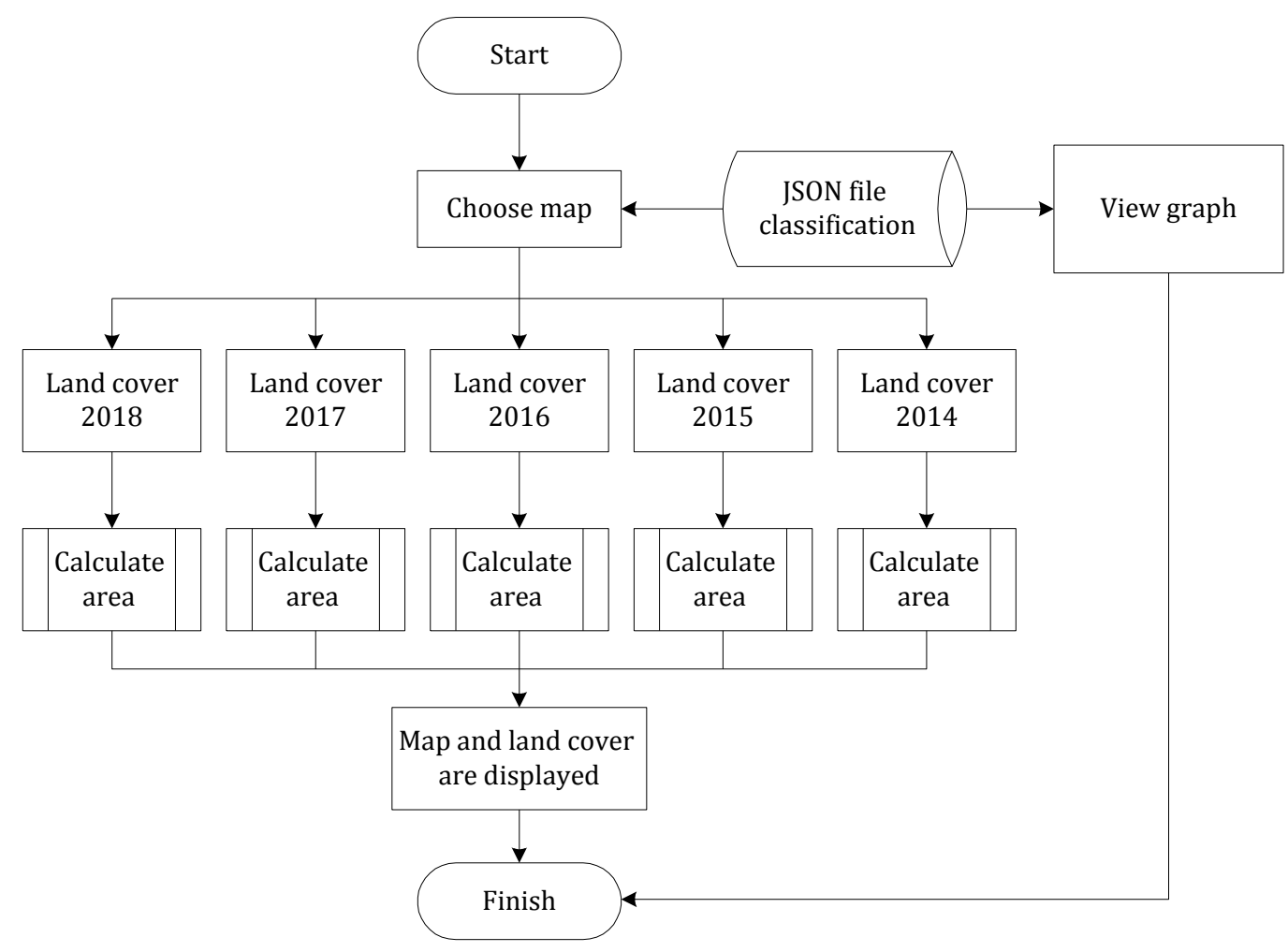

Figure 3. System workflow diagram

In Figure 3, it can be seen that the system workflow in this system started with the process of selecting maps to be displayed or shown in a graph. If you choose the map selection process, then the map was taken from the classification JSON file which was divided into five years of land cover. After selecting one certain year, the land cover map was then followed by a subprocess for calculating the total area of the land by calling and summing the area data of all polygons in each land cover class from the JSON file. Next map and area were displayed to the system. If the user chooses the process of displaying in the graph, then the process would take the annual land cover area data from the classification JSON file and displayed it on graphic media. The design of this DFD aims to describe the relationships built in the system. The DFD 
was designed in three levels, namely context diagram or level-0 diagram, level-1 diagram, and level-2 diagram.

Context diagram or also called level-0 diagram is the highest diagram in the DFD that describes the flow and relationship of the system with the environment in outline. The level-0 diagram of this system is shown in Figure 4.

Figure 4 shows a context diagram of the system, as this diagram has one process and one entity. The process described in the context diagram is the core process of the application to be built. While entities in context diagrams are users or people who will later interact with the system. From Figure 4 it can be seen that the user interacts with the system by entering/selecting the map year. Then the system finds the map year in the existing classification data and takes the land cover data based on that year. The system will display land cover information in the form of maps and details to users.

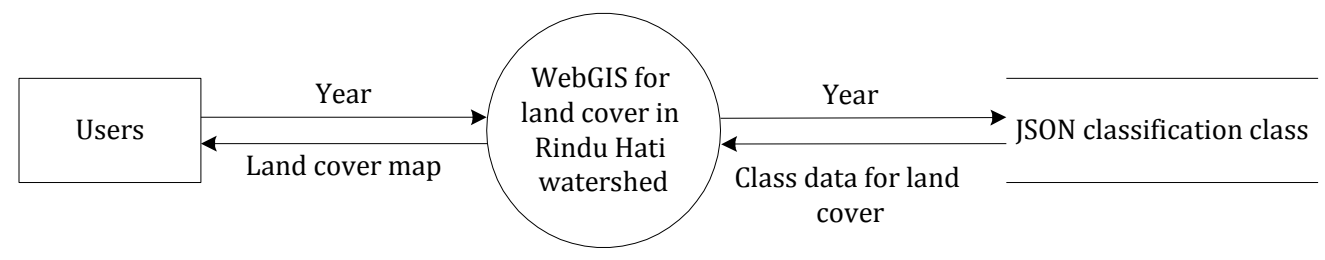

Figure 4. Context diagram (Level 0)

In level-1 diagram, there are 3 processes that describe the application for identifying the type of image to be built. The level- 1 diagram of this application is shown in Figure 5 and Figure 6.

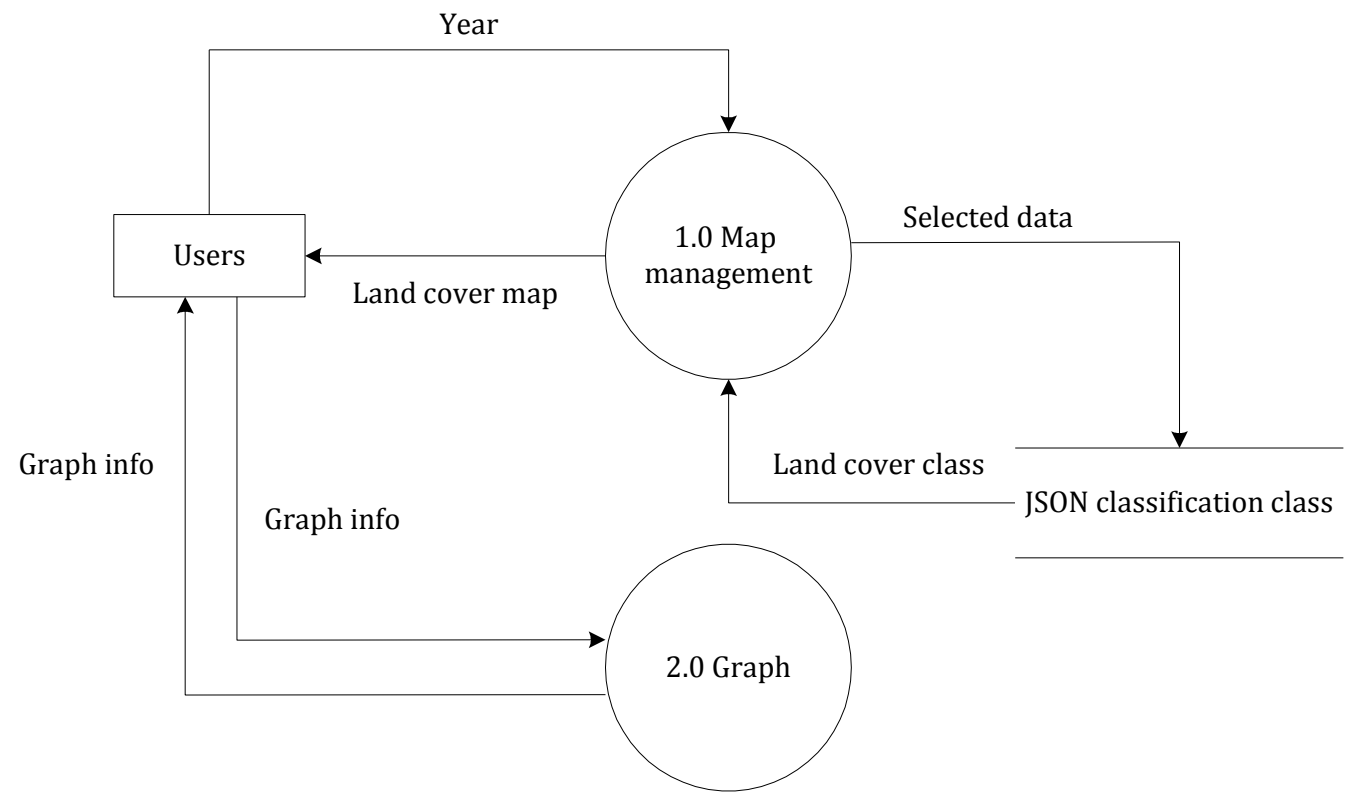

Figure 5. Level-1 diagram 


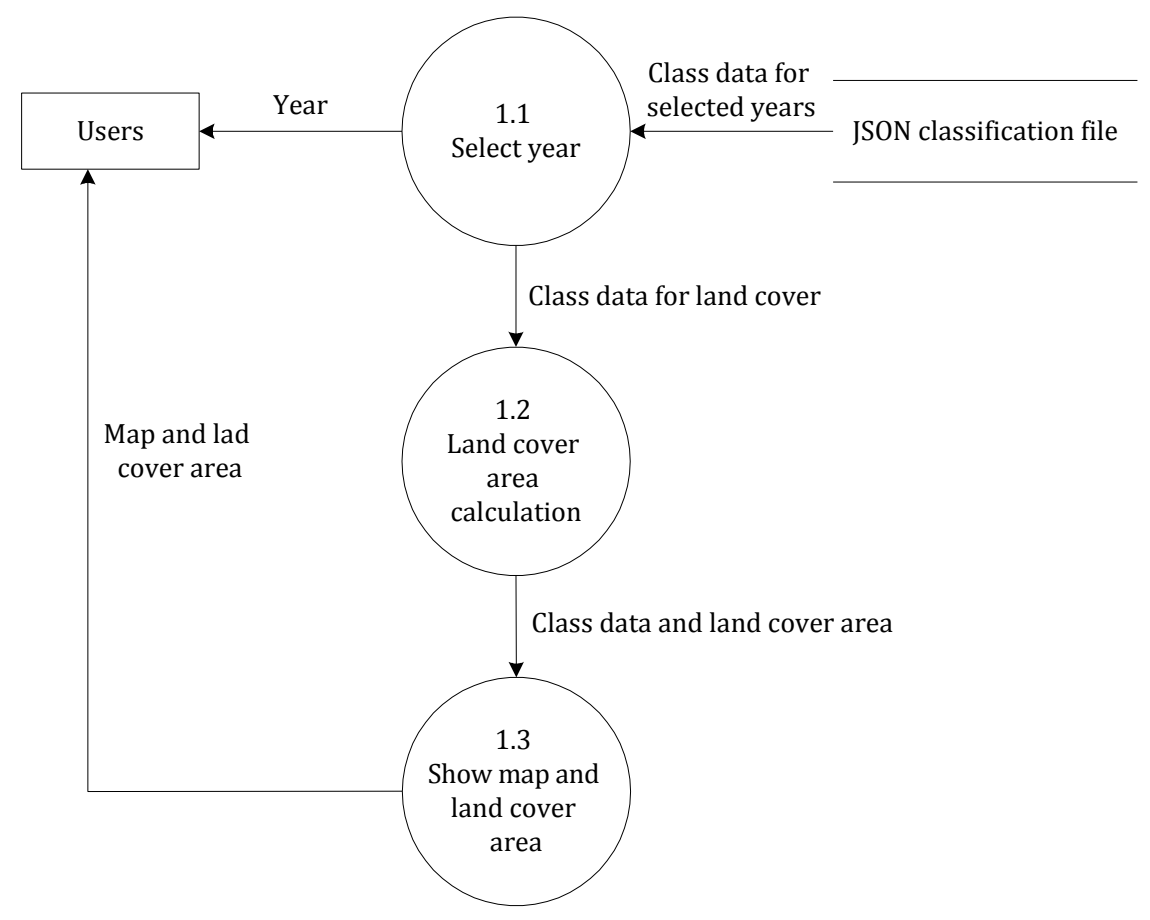

Figure 6. Level 2 diagram (Process 1)

- Process 1.0: Map management. In this process, the user selects the map year provided by the system, then the system will look for land cover class data according to the user's selected year. Then, the system processes the data and displays it in the form of map.

- Process 2.0: Graph. Process 2.0 is a process that provides information on land cover in the form of charts or graphs.

Process 1 in level-2 diagram of this application is shown in Figure 6. It shows process 2 of Level-2 diagram which has three processes. The first process was the map year selection process, started with the user entering/selecting the map year provided by the system. Then, the system retrieved the data from the classification JSON file and processed the data into a land cover class. Furthermore, the data were processed by the second process, namely calculating the area of each land cover class. Furthermore, the final process was to display the map and the area of land cover to the user.

The interface is a medium of interaction between the user and the system. So the interface is an important part of making an application. Before building an interface, an application needs to firstly design the interface, so that it can provide a clear and directed picture about the construction of the application interface, so as to produce an application that has an interface that matches the desires and needs. The interface design of the application to be built is as follows. 


\subsubsection{Implementation}

The main page in an application contains the main topics of the application. The main page in this application appears firstly when this application is running. The interface design of this system can be seen in Figure 7.

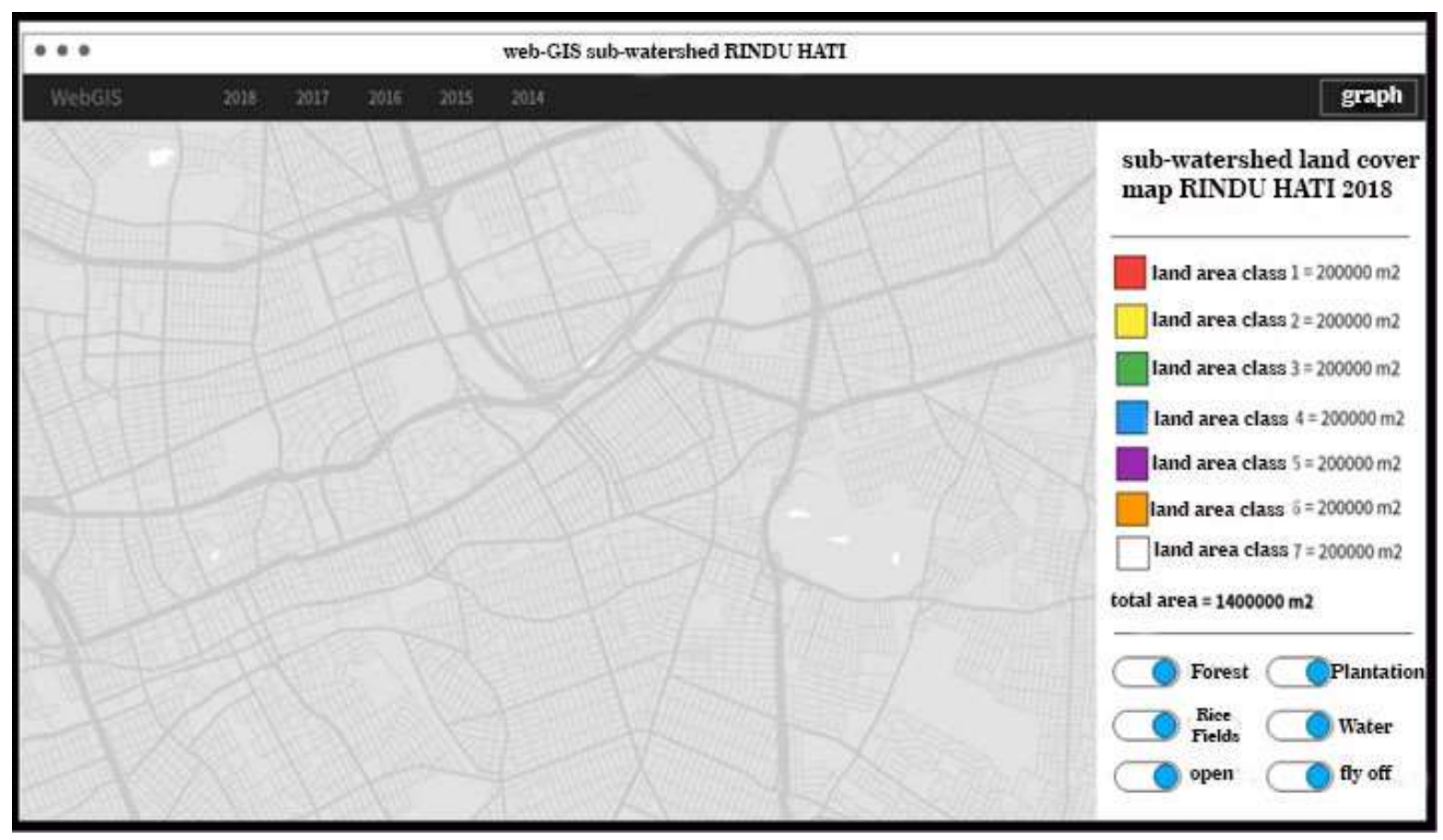

Figure 7. Interface design for main page

It can be seen in Figure 7 that the system main page interface of this study is divided into several parts, namely header, mainpage, and sidebar. The header is where the navigation menu is located. In the navigation menu, there are several buttons representing each year of the map, namely 2018, 2017, 2016, 2015, and 2014. In this menu there is also a 'graph' button on the right which serves to direct to the chart page when pressed. Then, there is the mainpage section, which is the part where the map is displayed. Next, the sidebar section displays the details of the land cover map displayed. These details are in the form of the class name, area, and year of land cover.

\subsubsection{Integration and system setting}

\subsubsection{Main page}

A web-based system was developed using php and javascript programming languages to display the results obtained from the stages in image processing, namely the land cover models. The results of the implementation of this stage consisted of the main and graph pages.

The main page in an application is a page that contains the main topics of the system. The main page on this system first appeared when the web was accessed. This page can be seen in 
Figure 8. The description of the pattern of the map in the page is decribed in Table 2. This page displays a map of land cover and the area of each land cover. Then, on this page, there are also 7 toggles to turn on and off each land cover.

Table 2. Classification description

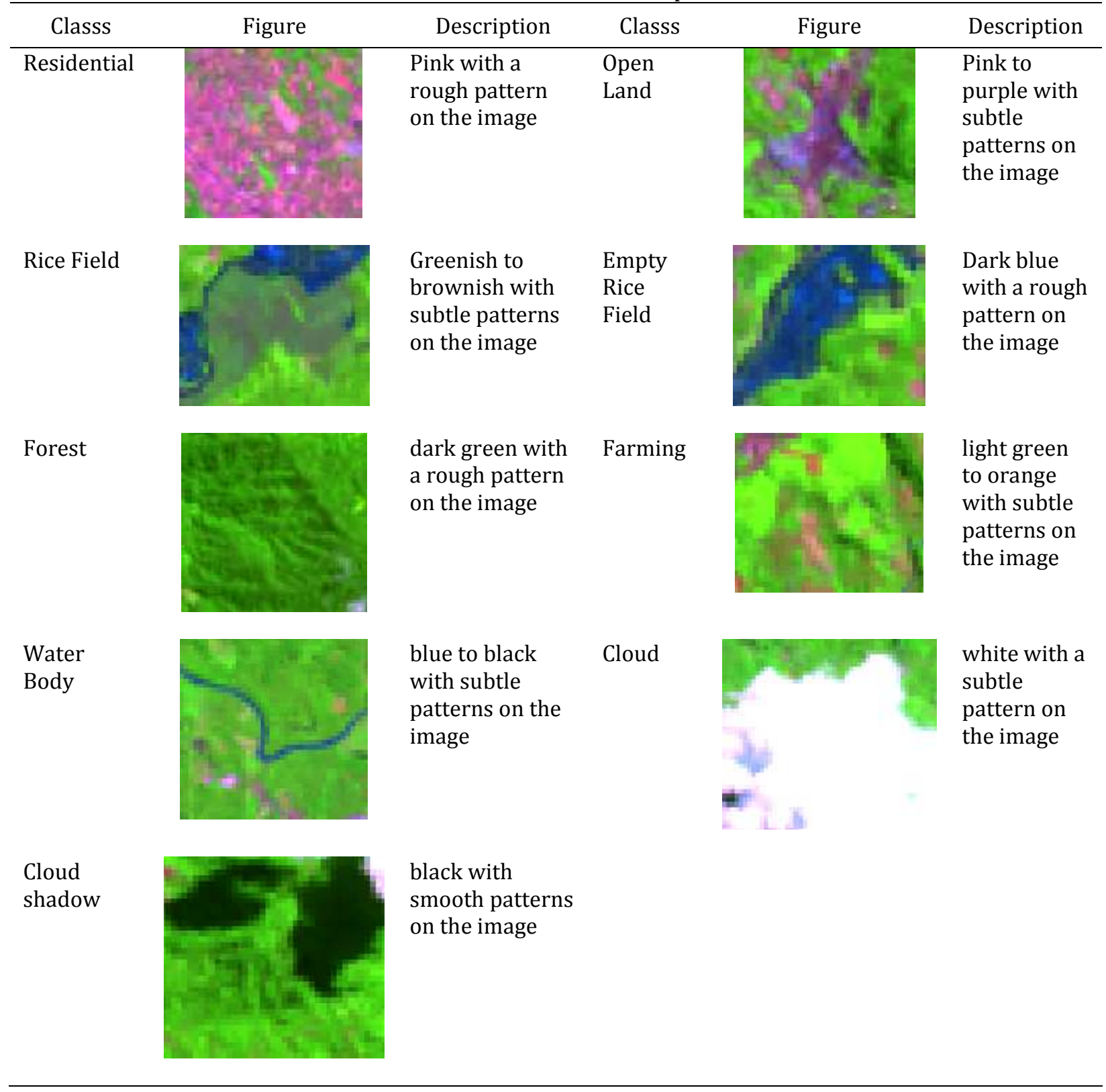




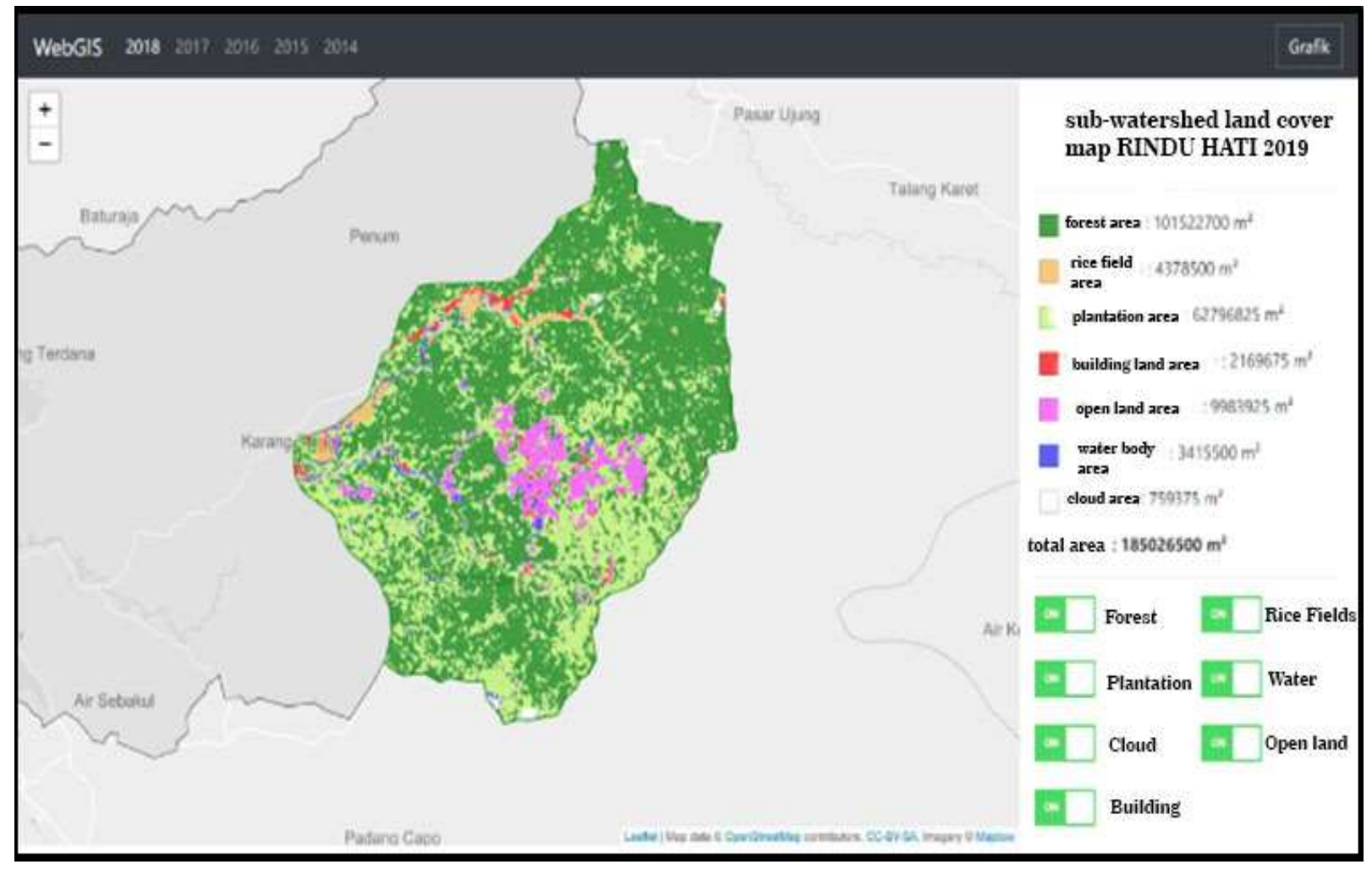

Figure 8. Main page implementation

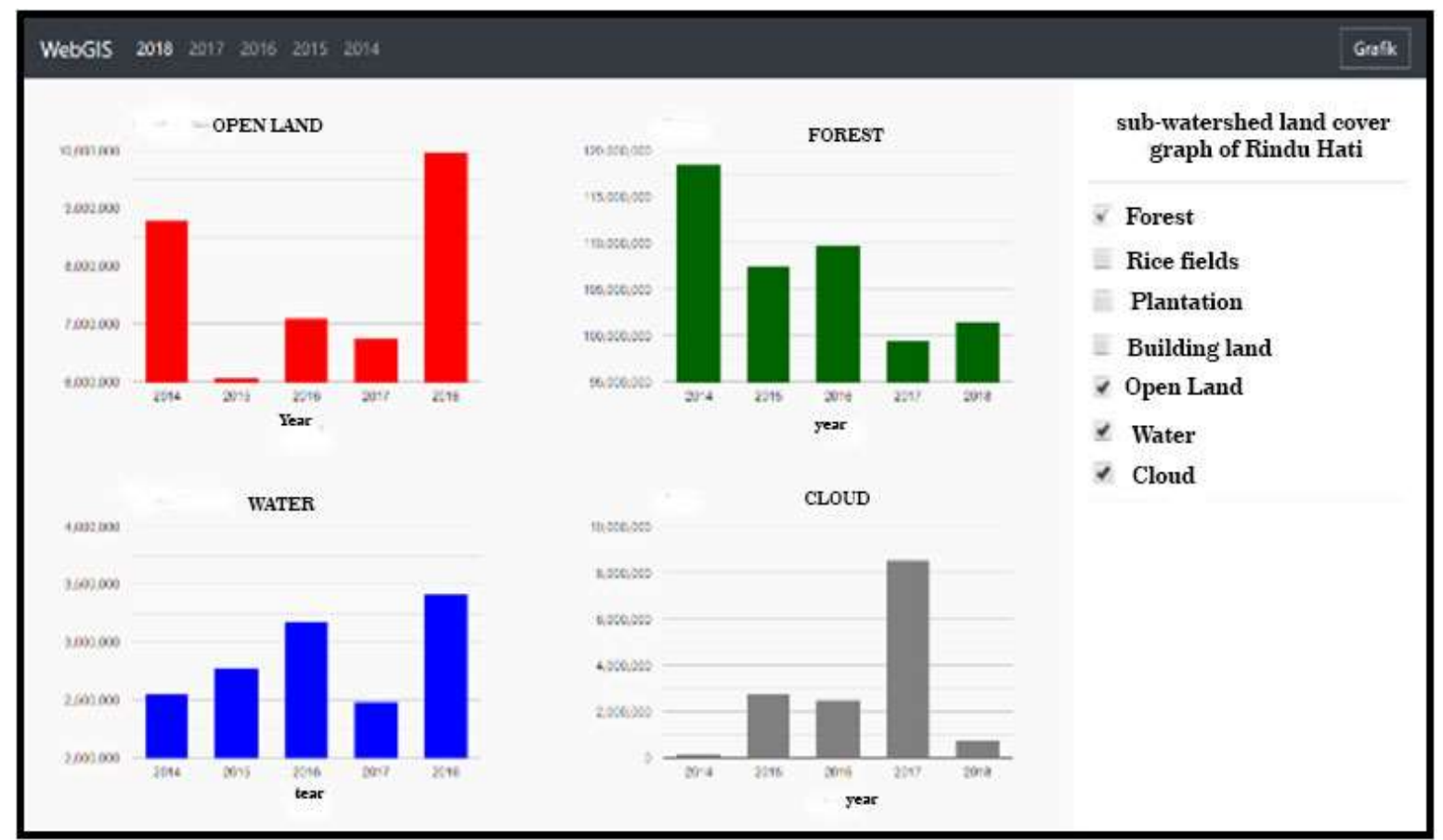

Figure 9. Graph page implementation 


\subsubsection{Graph page}

The graphic page appears when the 'Graph' button on the main page is clicked. On this page, the area of each land cover per year is displayed in graphical form. The results of the graph page implementation can be seen in Figure 9. Each chart is colored according to the color of the land cover displayed in the main menu. In the sidebar, there is a graph list that can be displayed or hidden according to the user's choice.

\subsubsection{Analysis result}

From the data presented in Table 3, it can be seen that the area of forest land cover decreased by $9.17 \%$ from 2014 to 2018 , from $64.06 \%$ to $54.87 \%$. An increase in the area of land cover by $0.93 \%$ from 2014 to 2018 , from $1.44 \%$ to $2.37 \%$. The area of plantation land cover increased by $6.69 \%$ from 2014 to 2018 , from $27.25 \%$ to $33.94 \%$. An increase in the area of land cover built by $0.14 \%$ from 2014 to 2018 , from $1.03 \%$ to $1.17 \%$. An increase in open land cover area by $0.65 \%$ from 2014 to 2018 , from $4.75 \%$ to $5.40 \%$. An increase in the area of land cover of water bodies by $0.47 \%$ from 2014 to 2018 , from $1.38 \%$ to $1.85 \%$.

Table 3. Classification result

\begin{tabular}{lrrrrr}
\hline & \multicolumn{5}{c}{ Forest area wide } \\
\cline { 2 - 6 } & \multicolumn{1}{c}{2018} & \multicolumn{1}{c}{2017} & \multicolumn{1}{c}{2016} & \multicolumn{1}{c}{2015} & \multicolumn{1}{c}{2014} \\
\hline Forest & $101,522,700$ & $99,422,100$ & $109,712,700$ & $107,478,900$ & $118,523,700$ \\
Rice fields & $4,378,500$ & $5,064,300$ & $6,332,400$ & $3,500,100$ & $2,661,300$ \\
Plantation & $62,796,825$ & $60,710,400$ & $54,095,200$ & $60,569,100$ & $50,424,300$ \\
Land Awakened & $2,169,675$ & $2,022,300$ & $2,085,500$ & $1,830,600$ & $1,903,500$ \\
Open field & $9,983,925$ & $6,757,200$ & $7,090,200$ & $6,069,600$ & $8,788,500$ \\
Water body & $3,415,500$ & $2,483,100$ & $3,186,000$ & $2,781,000$ & $2,558,700$ \\
Cloud & 759,375 & $8,567,100$ & $2,524,500$ & $2,797,200$ & 166,500 \\
\hline
\end{tabular}

Data on changes in overall land cover over the period 2014-2018 can be seen in Figure 10. It can be seen that, in the period of 2016-2017, there was a significant decrease in the percentage of forest land cover area of $5.56 \%$. However, this happened together with an increase in cloud area by $3.27 \%$ and an increase in the area of plantation land cover by $3.58 \%$. One of the reasons for the decrease in the area of forest land cover was due to cloud cover, where in the period of 2017-2018 the percentage of forest land cover increased by $1.14 \%$ along with the cloud area decreased by $4.22 \%$. Meanwhile, in the period of 2014-2015, the area of forest land decreased by $5.97 \%$ but accompanied by an increase in plantation area by $5.48 \%$. Another possible factor for the decrease in the area of forest land cover is the change in land use, one of which became plantation, as in the period of 2014-2018, the forest land cover decreased by $9.19 \%$ along with the increase in the area of plantation land cover by $6.69 \%$. 


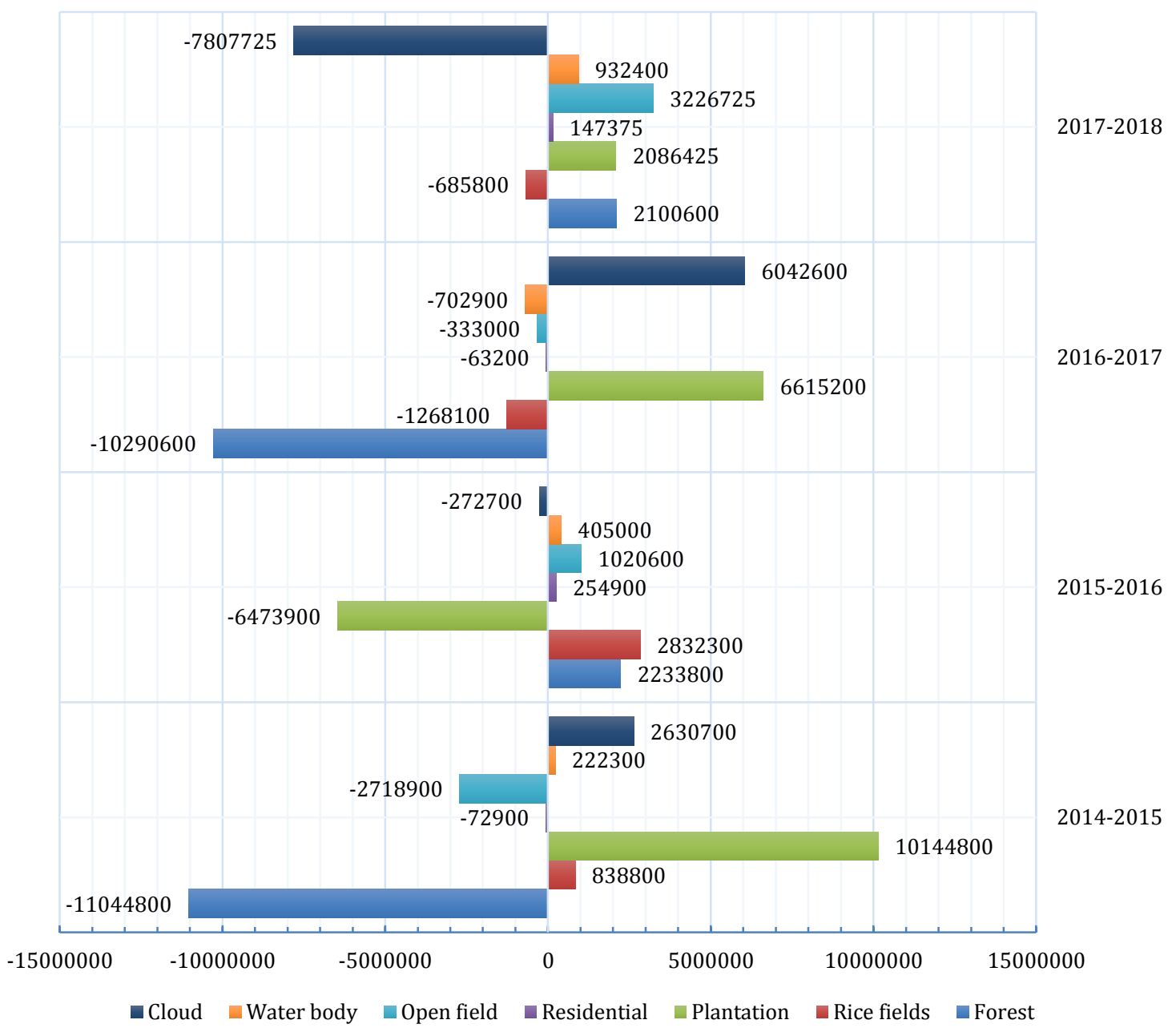

Figure 10. Gain and loss of land cover area

\subsubsection{Testing phase}

The method of testing the accuracy of land cover used in this study was by doing groundcheck and interpretation of digital images at scattered points on the study area to measure the level of accuracy of the land cover mapping model with land cover in the field. From 62 scattered test points, the test data were taken through digital image interpretation using the Google Earth Pro and ground-check applications on the field and there were only 48 identifications that were accurate or in accordance with the land cover on the field. From this result, the accuracy of the system for classification of land cover maps was calculated as follows.

$$
\text { Accuracy }=\frac{48}{62} \times 100.00 \%=77.4 \%
$$

Thus, the accuracy test of land cover was 77.4\% (Prabhakara et al., 2015). This accuracy is acceptable, as the image quality in this result still has noise from cloud that could make the classification process. Further assessment of the validation can be improved by using the percentage of pixel and another classification result with the same image. Some of the data 
validation have been done by doing the ground truth to the location of classification can be seen in Table 4.

Table 4. System testing result

\begin{tabular}{lll}
\hline \multicolumn{1}{c}{ Testing Activities } & \multicolumn{1}{c}{ Realization } & \multicolumn{1}{c}{ Results } \\
\hline Click on the 2018 Button works & The 2018 land cover map page appeared & Succeed \\
Click on the 2017 Button. & The land cover map page of 2017 appeared & Succeed \\
Click on the 2016 Button & The 2016 land cover map page appeared & Succeed \\
Click on the 2015 Button. & The 2015 land cover map page worked & Succeed \\
Click on the 2014 Button. & Appeared on the 2014 land cover map page & Succeed \\
Click on Forest Toggle & Show/Hide forest land cover & Succeed \\
Click on Toggle Rice Field & Show/Hide the cover of rice fields & Succeed \\
Click on Toggle Farming & Show/Hide plantation land cover & Succeed \\
Click on Water Toggle & Show/Hide the land cover of the water body & Succeed \\
Click on Toggle Cloud & Show/Hide cloud cover & Succeed \\
Click on Open Toggle & Show/Hide cover of open land & Succeed \\
Click on Toggle Build & Show/Hide cover of built-in land & Succeed \\
Click on the Graph Button to appeared. & The land cover graph display page & Succeed \\
Click on the Forest & Checked box/Hidden forest chart & Succeed \\
Click on Rice Field & Checked box/Hidden rice field chart & Succeed \\
Click on Plantation Checkbox & Show/Hide rice fields graph & Succeed \\
Click on Built-in Land & Checked box/Hidden graph of built land & Succeed \\
Click on Open Land & View/Hide land & Succeed \\
Check on the box of graph of open land & Checked box/Hidden water body checkbox & Succeed \\
& graph of water body & \\
Click on Cloud & Checked box/Hide cloud chart & Succeed \\
\hline
\end{tabular}

\section{Conclusion}

This study has succeeded in making a mapping model of land cover areas in the Rindu Hati Sub-watershed area using imagery from Landsat 8 satellite with an accuracy rate of $77.4 \%$. This study has also succeeded in displaying information about land cover in the area of Rindu Hati Sub-watershed on WebGIS media that could possibly forward the analysis of green belt in Bengkulu (Febrianti \& Sofan, 2014).

This study has successfully displayed information about land cover in the Rindu Hati Subwatershed area through WebGIS media. The most significant change in land cover was the decrease in forest cover by $9.17 \%$ in the period of $2014-2018$, from $64.06 \%$ to $54.87 \%$, or about $1.7 \mathrm{kHa}$. The increase in the area of plantation land cover was $6.69 \%$ in the period of $2014-2018$, from $27.25 \%$ to $33.94 \%$, or about $1.2 \mathrm{kHa}$, which was indicated as the largest substitute for forest land cover. The results of this study could be beneficial for disaster analysis (Syihab, 2008) and land use change policy (Direktorat Kehutanan dan Konservasi Sumberdaya Air, 2008) to be improved in the future. This model showed a dynamic change over watershed that was not based on the standard of watershed cover to improve the sustainability of the surrounding environment of the watershed (Andriansyah \& Mustikasari, 2011; Arrofiqoh, 2014). This could be the initiation study to see the further impact of flood caused by the misleading direction of watershed management in Bengkulu (National Science Foundation, 2016; Somantri, 2014). 
Further direction could also involve the algorithm (Utama et al., 2018) to improve the result of classification.

\section{References}

Ambarwati, W., \& Johan, Y. (2016). Sejarah Dan Perkembangan Ilmu Pemetaan. Bengkulu: Universitas Bengkulu.

Andriansyah, O., \& Mustikasari, R. (2011). Mustikasari Rita Gambaran Umum Permasalahan Pengelolaan Air Das Air Bengkulu. Telapak.

Arhatin, R. E. (2007). Pengkajian Algoritma Indeks Vegetasi Dan Metode Klasifikasi Mangrove Dari Data Satelit Landsat-5 Tm Dan Landsat-7 Etm+ (Studi Kasus Di Kabupaten Berau, Kalimantan Timur). Institut Pertanian Bogor.

Arrofiqoh, E. N. (2014). Pemantauan Kawasan Sabuk Hijau Waduk Wadaslintang Menggunakan Citra Satelit Landsat 8. Universitas Gadjah Mada.

BPDAS Ketahun. (2006). Profil Kondisi Daerah Aliran Sungai Air Bengkulu. Bengkulu.

BPS. (2017). Laporan Data Statistik. Jakarta.

Budiani, N. (2010). Data Flow Diagram: Sebagai Alat Bantu Desain Sistem. Jakarta: Departemen Keuangan.

Departemen Kehutanan Republik Indonesia. (2009). Kerangka kerja pengelolaan daerah aliran sungai di Indonesia. Amanah instruksi Presiden No. 5 Tahun 2008 tentang fokus Program Ekonomi Tahun 2008-2009.

Direktorat Kehutanan dan Konservasi Sumberdaya Air. (2008). Kajian Model Pengelolaan Daerah Aliran Sungai (DAS) Terpadu. Jakarta: BAPPENAS.

Febrianti, N., \& Sofan, P. (2014). Ruang Terbuka Hijau Di Dki Jakarta Berdasarkan Analisis Spasial Dan Spektral Data Landsat 8. In Prosiding Seminar Nasional Penginderaan Jauh 2014. Bogor: LAPAN.

Gunawan, G. (2014). Model Optimasi Alokasi Lahan DAS dengaan Integrasi Antara GP dengan GIS. Universitas Indonesia.

Guritno, S., \& Rahardja, U. (2011). Theory and Application of IT Research Metodologi Penelitian Teknologi Informasi. Yogyakarta: Andi Offset.

Irwansyah, E. (2013). Sistem Informasi Geografis: Prinsip Dasar dan Pengembangan Aplikasi. Yogyakarta: Digibooks.

Kodontie, J. R., \& Syarif, R. (2010). Tata Ruang Air. Yogyakarta: Andi Offset.

Muhsoni, F. F. (2009). Pemetaan Kerapatan Mangrove di Kepulauan Kangean Menggunakan Algoritma NDVI. Jurnal Ilmu Kelautan Universitas Trunojoyo, 10, 23-31.

Mulyanto, A. . (2008). Rekayasa Perangkat Lunak Jilid 1. Jakarta: Direktorat Pembinaan Sekolah Menengah Kejuruan.

National Science Foundation. (2016). Science and Engineering Indicators 2016. Retrieved 
November 17, 2019, from https://www.nsf.gov/statistics/2016/nsb20161/\#/

Prabhakara, K., Hively, W. D., \& McCarty, G. W. (2015). Evaluating the relationship between biomass, percent groundcover and remote sensing indices across six winter cover crop fields in Maryland, United States. International Journal of Applied Earth Observation and Geoinformation, 39, 88-102.

Pratama, A. (2015). PHP Uncover - Panduan Belajar PHP untuk Pemula. Bandung: Penerbit Duniailkom.

Pratama, A. (2017). JavaScript Uncover - Panduan Belajar JavaScript untuk Pemula. Dunia Ilkom.

Presiden Republik Indonesia. Peraturan Pemerintah Republik Indonesia Nomor 37 Tahun 2012 Tentang Pengelolaan Daerah Aliran Sungai Dengan Rahmat Tuhan Yang Maha Esa (2012). Indonesia.

Purwanto, D. (2014). Aplikasi Sistem Informasi Geografis Berbasis Webgis Pemetaan Sanggar Seni Di Kota Pangkalpinang. Sekolah Tinggi Manajemen Informatik dan Komputer Atma Luhur.

Somantri, Y. G. (2014). Analisis Kapasitas Sungai Dalam Mengendalikan Banjir Dengan Integrasi Antara Metode Rasional Dengan Program Win-Tr. Universitas Bengkulu.

Sommerville, I. (2010). Software Engineering. London: Wiesley Pub.

Susilo, B. (2011). Pemodelan Spasial Probabilistik Integrasi Markov Chain Dan Cellular Automata Untuk Kajian Perubahan Penggunaan Lahan Skala Regional Di Provinsi Daerah Istimewa Yogyakarta. Jurnal Geografi Gea, 11(2), 163-178.

Syihab, U. (2008). Mencerdasi Bencana. Jakarta: Grasindo.

Utama, F. P., Vatresia, A., \& Wijanarko, A. (2018). ValidasiMatrix completion pada Deteksi Hasil Klasifikasi Alih Fungsi Lahan sebagai Inisiasi Penanggulangan BencanaKota Bengkulu. Bengkulu.

Vatresia, A., Sadler, J. P., \& Rais, R. R. (2017). Resort Based Management Web-GIS: Towards Cyber Conservation in Indonesia. Sustinere: Journal of Environment and Sustainability, 1(1), $10-22$.

Vatresia, A., Sadler, J. P., \& Rais, R. R. (2017). The development of mobile application for conservation activity and wildlife in Indonesia. In 2016 ICINA (pp. 203-208). Jakarta.

Wahyuni, S. (2015). Identifikasi Karakteristik Dan Pemetaan Tutupan Lahan Menggunakan Citra Landsat 8 (Oli) Di Kabupaten Ogan Komering Ilir Provinsi Sumatera Selatan. Institut Pertanian Bogor.

Waluyaningsih, S. R. (2008). Studi Analisis Kualitas Tanah Pada Beberapa Penggunaan Lahan Dan Hubungannya Dengan Tingkat Erosidi Sub Das Keduang Kecamatan Jatisrono Wonogiri. Universitas Sebelas Maret. 